\title{
CORRUPTION AND THE MEDIA - A JOURNALISTS' LOOK ABOUT THE RELEVANCE OF TIME
}

\author{
Ana Moreira, Emília Araújo \& Helena Sousa
}

\begin{abstract}
The relations between the media, politics, the legal system and the phenomenon of corruption are complex and gives rise to various types of time and temporality. In empirical terms, this text addresses a study conducted with journalists who have followed cases of corruption involving politicians. The importance of time in the constitution of relations between media, politics and the legal system is discussed. The analysis highlights some of the main characteristics of the time in the media labour. Additionally, it debates the way in which time configures the relations of power that are established between the different systems and actors.
\end{abstract}

KEYwORDS

Political corruption; justice; media; politics; time

\section{A CORRUPÇÃO E OS MÉDIA - UM OLHAR DOS JORNALISTAS SOBRE A RELEVÂNCIA DO TEMPO}

Resumo

As relações entre os média, a política, o sistema judicial e o fenómeno da corrupção são complexas e inscrevem-se em vários tipos de tempo e de temporalidade. Neste texto, a partir de um estudo empírico qualitativo conduzido junto de jornalistas que fizeram acompanhamento de casos de corrupção envolvendo políticos, discute-se a importância do tempo na constituição das relações entre média, política e o sistema judicial. A análise permite destacar, por um lado, algumas das principais caraterísticas do tempo no trabalho mediático, e, por outro, a forma como o tempo configura as relações de poder que se estabelecem entre os diversos sistemas e atores.

\section{INTRODUCTION}

This paper focuses on the relevance of time and temporality by analyzing the way in which the media convey the phenomena of corruption involving accusations against politicians. It is intended to demonstrate that time mediates the relationship between journalists, politicians and judicial entities, giving to know more about the interdependencies between the media, political and the judicial system. 
There are several cases of corruption involving politicians. Some of them are proven. Others are only object of suspicion. Corruption involves actions with negative effects for democratic systems. It paves the way for the decrease of citizens trust in politics. Although corruption occupies prominent space in regulation (from economics to politics), democratic countries are still marked by successive scandals that directly or indirectly involve people performing political roles (Paixão, 2014, 2017). The succession of these cases and the magnitude of their effects are some motives to classify the phenomenon as a "social pathology" (Ferin, 2017). Besides institutional disbelieving, it promotes the potential normalization of unlawfulness and unethical behaviors.

This text aims to explore the relevance of time in the establishment of mediations between justice, politics and media. In this sense, the corruption phenomenon is used in as heuristic way. That is, to demonstrate the main temporal dimensions for the constitution of the mediatic phenomena that imply journalists, politicians and people working in judicial system. It is not, therefore, the purpose of this article to deepen the problem of corruption involving politicians, but to give an account of journalists' perceptions of the importance of time and temporality in the definition of the relations they establish and can establish with both politicians and judicial actors.

As we shall see below, the problematization of time and temporality in media is still scarce today. The same happens concerning the relations between media, politics and justice. We will mobilize existing approaches about the acceleration and speed in postmodern societies in order to better understand these relationships. We will highlight the need that media, justice and politics have to provide ways to strengthen their qualification in issues of time and temporality, contributing to the improvement of communicative action in democracy.

In empirical terms, the text is based on the analysis of content made to interviews with journalists who did publications concerning news related to cases of corruption in Portugal. It is structured in four main points. First, there is a problematization about the corruption issue in the media. The next point refers to the main theoretical approaches dealing with media, time, politics and law. The third point describes the methodology followed in the study. In the last point, we present some final notes, as well as the contributions to understand the relevance of time in the constitution of the media-politics-justice relationships.

\section{THEORETICAL FRAMEWORK}

\section{CORRUPTION AND MEDIA}

Isabel Ferin and Estrela Serrano (2014), analyze the corruption enacted by politicians. They argue that it must be perceived "as the abuse of power for its own benefit of democratically elected political agents - a situation that may occur during or after the exercise of public functions" (Ferin \& Serrano, 2014, p. 8). Corruption is a phenomenon that links to power relations (Sousa, 2011). It is made explicit by the existence of a pact. In Luís de Sousa's view, corruption involves a context, actors, ethical predisposition to violate the law or act dishonestly, resources and power, strategic trust and exchange processes. 
For the purpose of this text - the analysis of the relevance of time in the way the media deal with cases of corruption, highlighting the main temporal relations between media, justice and politics - it is important to clarify some ideas about the relationship between media, justice and politics in face of corruption situations, in order to understand why it is a phenomenon that is favorable to time overlapping and conflicts.

We can say that the way in which corruption becomes the object of the work of the media is a matter of great controversy. On one hand, there is a wide range of legal criteria that needs to be gathered for the judgement to take place. On the other, corruption is a phenomenon that assures scandal and revenues for media industry. Being or not judicially proved, any case involving the accusation of politicians is likely to quickly become a rhizomatic temporal phenomenon in which multiple actors and institutions will participate in redesigning new connections that shift times, spaces, and powers. Pier Paolo Giglioni (1996) argues that the media show different positionings concerning corruption phenomena involving politicians: they can find out the case, make it public, known, or favor the social construction of the scandal. According to this author, media are the main source of public information about corruption. Therefore, the attention and the way they conceive and convey the contents are fundamental, even in democracies (Giglioli, 1996) to understand the quality of institutions and of democratic processes, transparency and ethics. Luís de Sousa considers that media are an "integral part of the anti-corruption infrastructure" (Sousa, 2011, p. 72), but since corruption has a high news value, it becomes subject to relations of power which are established between media, justice and politics, and which are "reciprocally instrumental, oscillating between collaboration and conflict" (Sousa, 2011, p. 72) and highly mediated by the struggles for control and domination over time - of processes and information.

Ferin (2014) argues that the media coverage has undergone great technological, economic, financial and social changes that have led to alterations in the way politics is enacted (Ferin, 2014, p. 373). Affirming that corruption is a kind of subject in which the media has power of selection and construction, the author analyzes the case BPN, Freeport and Face Oculta, as well as of the elections affirming that the media coverage is a "controversial subject" that involved accusations between politicians, journalists, other people working in justice fields; information leaks (of confidential elements); transcriptions of wiretapping; and (all of this gave rise to) criminal investigations of journalists and media (Ferin, 2014). Ferin (2014) considers that there is great vulnerability to corruption, as this is a phenomenon that normally follows each other in cascade, that is, "when the coverage of one case decreases in intensity, another case replaces it and reaching greater intensity" (Ferin, 2014, p. 398).

As far as television is concerned, the authors consider that the channels dedicate disparate times for each piece (more time in TVI and less time in RTP1), as frameworks are preferentially episodes (Ferin, 2014, p. 404), centered on an "issue", which may be a fact, a political actor or a scenario. In turn, Paixão (2014) advances that that corruption news comprises some of infotainment features with "allusion to the preparation of the conference, the emotional character, the clothes, the props and the hairstyle, the 
observations of the lawyer" (Paixão, 2014, p. 486). In the opinion of the journalists interviewed by this author, the spectacle-scandal guarantees success in the audiences producing great liminality and suspension.

Prior and others (2015) analyze and compare the cases Face Oculta (Portugal) and Mensalão (Brazil), giving importance to temporality. They analyze how this is inscribed in the narrative of other characters, while making them appear and disappear according to the intended impact:

temporality is thus linked to the capacity of organizing the fragmented events of previous editions and to tell a more complex "story". The "when" and the "how" are converted into verbal frames establishing the narrative of the scandal, specifically because they allow the reader to situate him/herself in the time of events, to help the journalist/narrator organize the enunciative time and, therefore, the journalistic discourse itself. (Prior et al., 2015)

A bulk of national and international works analyze the mediatization of justice (Boda \& Szabó, 2011; Greer, 2009; Guibentif et al., 2002; Jewkes, 2004; Lourenço, 2013; Machado \& Santos, 2008, 2009, 2010, 2011a; Machado, 2008). The studies assert that it holds high news-value (Araújo, 2013; Boda \& Szabó, 2011; Greer, 2009; Jewkes, 2004; Karstedt, 2002; Leandro, 2012; Machado \& Santos, 2008, 2011b; Newburn, 2007; Peelo, 2005; Reisinger, 2007).

Jewkes (2004) names twelve parameters to analyse the concept of news-value. Some of them refer to time: threshold character, predictability, simplification, individualism, risk, sex, celebrity or high social status, proximity, violence, spectacularism or graphic images, children and conservative ideology and/or political entertainment.

Reisinger (2007) concludes that crime news has fueled public's fascination for violence. With the emergence of the popular press in the UK, police reports have proved to be prime sources of news of sensationalist potential. In France, the three main channels ( $\mathrm{TF}$, France 2 and France 3 ) devote twice of the time to these topics, when compared to economic and social issues. They also devote much more time to them, when compared to the time used to explore political issues - the exceptions are the electoral campaigns. In Spain, crime appears frequently in media and the references to it have almost doubled, while statistics on real crime have declined or stabilized. The Portuguese case also follows that trend (Pina, 2009).

Society has developed an "voracious appetite for diversion and narratives about control" and is increasingly "starving" (Greer, 2009) for crime-related contents. This may explain the persistent and continuous media interest in judicial matters (Araújo, 2013). Araújo (2013) shows the pertinence of "three characteristics transversal to the media narratives on crime, both in the investigation phase and in the resolution of the litigation, that is, the trial: serialization, personification and commodification" (Araújo, 2013, p. 18).

Surette (2011) argues that media judgment is mirrored in the ways crimes are developed and advertised as entertainment stories. Therefore, they are linked to the modes in which events and information circulate and are recycled. The same author shows the 
importance in perceiving the way the media are divided into type (print, visual, audio and new media) and content (entertainment, advertising, news and infotainment). In media judgments, media themselves feed almost instantaneously direct and individualized explanations for crime, such as lust, envy, immorality, greed, revenge, and insanity (Surette, 2011). From this point of view, media are subjected to temporality and times that characterize each historical moment. But they are also mobilizing agents and producers of temporalities, acting for the construction of corresponding times (compared to other instances, including the importance of the contents and of what can happen and the instantaneity (the need to generate contents about the cases, continuously and for a certain period of time). To a large extent, this mobilization towards anticipation and projection is due to the enormous changes that have permeated the communication fields, due to the development of technoscientific and digitisation.

\section{THE TIME AND THE MEDIA}

Although time has been addressed in several publications, authors tend to clarify what we might call temporal turn, that is, the concern with the relevance and salience of time and temporality in the analysis of media phenomena in informational capitalism.

David Clarke (1995), in an alignment that approaches the thinking of authors such as Richard Sennet (2006) or ljurn Appadurai (1996), considers that it is vital to include space and time in the study of media phenomena, in particular by looking at how media shapes time use patterns. John Robinson, Kevin Barth and Andrew Kohut (1997) analyze the effects of computer on the uses of time. In their view, the computer has been more effective than television in reconfiguring citizens' daily behavior. Howard Rosenberg and Charles Feldman (2008) speak of the "velocity errors" in the media. These, driven by the increasingly rapid logics of content dissemination, obstructs the production of truth, and fuels the circulation of speculation, triggering cultural and political consequences, affecting the time of the relations between citizens and their representatives.

Mira Moshe (2011) analyzes the "temporal configuration of the media", exploring how they privatize time, namely by controlling the schedules as well as the time flow settings. In Emily Keightley's book (2012) time and its visceral but fluid relationship with the media emerges as a central, yet invisible and systemic dimension. Eric Lee (2014) proposes a semantic analysis of media meanderings with the inclusion of time and temporality analysis in the construction of interactive systems. Kenzie Burchell (2014) focuses on everyday interactions, highlighting how information and communication technologies model temporalities in interpersonal relationships as well as the configurations of the activities. Anne Kaun (2014) explores time on social networks, giving relevance to Facebook, arguing that these are platforms for structuring social time, including processes of memorization. Sarah Coyne and others (2014) focus on the impact of the media on the times of families with adolescents, showing that media time is a kind of duration that contributes positively for family interactions in entertainment activities, emotional connection, discussion, information and documentation. 
Guobin Yang and Rosemary Clark (2015) discuss the presence of historical time in social media, revealing that the former establishes modes of periodization of time, with effects on the way of historical change is perceived. Alan Albarran and Arrese Angel (2015) contribute significantly to the understanding of media time by looking at how the media industry uses citizens' time uses to create new services. Matthew Jones and Joan Ormrod (2015) analyze how media content deals with time and makes it the specific object of its products. Lorna Jowett, Kevin Lee Robinson, and David Simmons (2016) present a series of analyzes on how narratives are a powerful object of media content. They argue that time is itself a prime consumer element that media uses in order to attract audiences attention.

Xiaoqun Zhang and Louisa $\mathrm{Ha}$ (2015) argue that we live in a context of great media abundance. They argue that people with more tight budgets (longer working hours and less leisure time) spend less time using traditional media means than people with more stress-free time budgets (more leisure time and less working time). In addition, people with less flexible time budgets allocate more time to new media, than people with more flexible time budgets.

Anne Kaun (2015) relates the time regimes with practices of media consumption analyzing more disadvantaged social groups. She demonstrates that time regimes that profit of technical acceleration are successfully appropriated by the social groups. The author questions the relationship between time regimes, media and democracy, proposing that the new media, favoring the increase of speed and acceleration, may lead to the eruption of frequent affirmative and protest movements. Emily Keightley and John Downey (2017) echo the idea that technical acceleration implies "lightening" the whole process of producing and disseminating information. According to the authors, this acceleration must be thought from the point of view of the positive effects it has on the consumption of news and the more generalized access to information.

Kevin G. Barnhurst and Andrew W. Nightingale (2017) consider that digitization is bringing a great deal of newness in the way one thinks, uses and constructs time, with effect on the practice of media professionals. They argue that the digital worlds produce (apparently) static structures of time which impacts on the process of collecting and disseminating information. Petter Bae Brandtzaeg and Marika Lüders (2018) explain that context in social media can disrupt the time gap between past and present, which, in turn, can affect how users manage their identity and performance in social media. Matt Carlson and Seth C. Lewis (2018) develop the concept of temporal reflexivity, proposing that time should be considered in the work of the journalists, especially as regards the way they deal with the past, present and future, favoring more or less public belief and representation about crisis, rupture or innovation.

$A$ vast set of analyzes has highlighted the changes in the temporal rhythms of the activities related to information collection and dissemination, due to technological and digital transformation. Correia (2006) refers to the subordination of "old" journalism to the spirit of the "new economy", marked by acceleration and speed. For Deuze and Witschge (2016) journalism is in the process of becoming a post-industrial profession, characterized by extemporaneity and emergent time: 
typically, the profession requires a certain type of compromise, but journalists in the digital age must commit themselves, above all, because their work is insecure, their salary is limited, public trust on them is precarious and their work extends beyond the deadline or the planned schedule. (Deuze \& Witschge, 2016)

Pereira and Adghirni (2011) say that deep changes are shaping different aspects of journalism and may radically alter the way it will be practiced in the future (Pereira \& Adghirni, 2011). In general, studies focusing on media and time are rather critical concerning two aspects: i) how states, organizations and people are dealing with the various accelerative trends; ii) how media are becoming a dominant temporality that structures historical, cultural and everyday times, defining new valid structures of time in terms of the organization of life, expectations and political-ideological understandings. In the middle there is the transformation of the activity of the journalist and of journalism, which is highly due to mobility and technical and social acceleration. But there are also changes concerning how institutions, including political and judicial institutions, produce time and deal with social rhythms acceleration, as well as with the speed of information circulation.

\section{TIME, MEDIA AND POLITICS}

Several authors, such as Luis Felipe Miguel (2002) and Sara Pina (2009), demonstrate that mediation has altered, to a great extent, the way of doing politics. Pina (2009) states that the mediatization of politics has transformed it into a "tele politics" (Pina, 2009), which has four consequences: hyper-personalization (centrality of the politician); the dramatization (political facts resemble narrative episodes or novels, in the author's words); fragmentation (emphasis given to non-verbal dimensions, such as images and voice, instead of using rational argumentation); and standardization, that is, the "standardization and standardization of political messages according to the media models" (Pina, 2009, p. 82).

Pina's (2009) proposal also suggests that politicians recognize this agenda and the need to adapt to media strategies and temporalities. Rémy Rieffel (2003) states that the mediatization of politics has transformed the modes of structuring politics and politics:

while political time is in the medium or long term, requiring analysis and deliberation, and should favor the memorization of what experts call "heavy political acts" (...) media time, on the contrary, is based on the direct, the ephemeral and speed. (Rieffel, 2003, pp. 27-28)

Traditional media have been forced to adapt and, at the same time, to incorporate these new digital platforms that imply different times and temporalities (Cardoso, 2014; Gurevitch et al., 2009; Luogo et al. 2011). Despite this incorporation transfigure and provide erosion of notions of time and space (Cardoso, 2014), journalists continue to be pivotal as mediators, ensuring the credibility of the information (Cardoso, 2014). William 
Croteau and David Hoynes reveal how a series of political processes have changed in response to the media, from the growing importance of the image and personality to the decline of political parties. In general, the authors tend to point out that the complexity of societies is so high today that policy responses are weakly adapted to the solution they propose to deal with the real problems of populations. First and foremost, the authors see political action as an over-centered action on the immediate response, far from legislative temporality and far from judicial temporality, which has consequences for the quality of participatory democracy (B. de S. Santos, 2005).

It is important to emphasize that the question of time is transversal to the studies that deal with narrative (Herman, 2004, Genette, 1976, 1979/1996, Ricoeur, 1994, Todorov, 1976). Katherine Young (2004) reflects on the interactive nature of face-to-face storytelling and describes the temporal flow of conversation through a spatial model', considering narratives as enclaves in the field of conversation (Young, 2004). More focused on the analysis of journalism from a narrative perspective, Robert W. Dardenne (2004) explains that although journalists call the articles "stories" they do not follow a narrative structure. This idea is central because it links to the more global changes that characterize journalism today, in a neo-liberal, global economy. A world in journalism becomes an activity subjected to new processes of acceleration. Helen Fulton and others claim in this context that media narratives do not exist, then, simply for entertaining the consumer, to tell stories. They say that they are manufactured in order to support the giant empires that run most of the media outlets (Fulton et al. 2005, p.4).

In the concrete case of corruption phenomena involving politicians, it is essential to also analyze thow time of justice influences media. The subject is complex and vast, since it refers to the interdependencies between several systems, each one of these selfreferential, if we use the language of Niklas Luhmann (1990, 2005).

Indeed, journalism and justice are different systems at two basic levels: temporal and linguistic levels. These basic differences end up generating asymmetries and incompatibilities (Fidalgo \& Oliveira, 2005; B. de S. Santos, 2005; F. Santos, 2009). The immediate and instantaneous times of communication are opposed to procedural times, clearly slower than the first (B. de S. Santos, 2005). An erudite, impersonal, objective, and impartial language of justice differs from the "direct and accessible language of the mass media" (B. de S. Santos, 2005).

But how are journalists effectively dealing with the various tensions that arise from various forms of acceleration? How do journalists deal with the agendas and times of the politicians themselves involved in corruption? How do these forms of acceleration coincide in politics and justice? What idea do journalists have of the influence that the acceleration of media times has on the times of justice? In this article we will try to debate the discourses produced by the journalists themselves about the relations between media, politics and justice and the role that time has in the construction of these relations and in their typologies.

'Young (2004) describes the conversation as a "back and forth" movement of the narrative, about the narrator's direction, but also with the initiative of the other participants (Young, 2004, p. 44). 


\section{EMPIRICAL RESEARCH}

\section{METHODOLOGICAL NOTE}

This article is based on a broader empirical investigation of journalists' perspectives on politician corruption and on relations with the judicial system (Moreira, 2015). This study included 30 interviews with journalists that we identified for their news work in cases of corruption. Journalists working in newspapers, television and radio stations in Portugal were interviewed. Eight interviews were conducted by e-mail, due to the interviewee's unavailability to perform the face-to-face interview. Most of the interviews (22) were carried out in person. The average interview time was one hour and five minutes. The interview sites were always chosen by the interviewee.

According to the theoretical framework, the guide was divided into three central dimensions of analysis about the perspectives and representations of journalists on: political corruption and its implications for credibility and trust in democratic institutions; the members, times and documents of the Justice, particularly articulated with the cases of corruption; the political and the Portuguese politicians when faced with cases of political corruption.

The interviews were analyzed using the Thematic Analysis (TA), following the proposal of Victoria Clarke and Virginia Braun (2013) that highlight six phases for the accomplishment of TA: 1) familiarization with empirical data, 2) coding (analytical), 3) search for themes (patterns present in the data), 4) review of the themes (articulation of the themes with the content of the collected data), 5) definition and final naming of themes (it implies an in-depth reflection on what the theme found and how it can be explained within the context and object of study - identify the "essence") and 6) the detailed writing (analytical narrative that brings together the themes of the data collected with the theoretical revision carried out).

As mentioned, we only analyze in this text the remarks made by journalists about the relevance of time in the establishment of relations between the media and justice and media and politics. The analysis made it possible to define two central themes: the acceleration of news periods and their effects on the journalist's work in situations where there are allegations of corruption; the relevance of waiting in the definition of relations between average and justice. In the next few points we are going to analyse these two themes.

\section{EMPIRICAL ANALYSIS}

The analysis of content to interviews confirms much of the ideas debated and explored in the theoretical framework. For journalists, justice is characterized as slow, and marked by the delay; while the media - designating spaces where they work - are driven by the need to respond to requests instantaneously, particularly when it comes to news involving politicians. The entire group of interviewed journalists agree with this time division, between the media system and the judicial system, as well as with the current trend towards online information production and the difficulty in obtaining appropriate waiting times for further research before publishing uncertain contents. 


\section{THE EMERGING AND INSTANTANEOUS TIME}

The journalists who were interviewed consider that, when facing cases of corruption (often only presumed), the media respond in an emergent and "anticipated" way, they struggle to get the news in "firsthand". The rapid way in which information circulates is responsible, therefore, for moments of disruption and controversy over time. This happens both in politics - which channels attention and criticism, getting enclosed in a time of proof; as in justice - which is affected by the search for information and opinions, some of which jumping from the physical space of judicial institutions, to the instantaneous and continuous time of the public judgement, which is typical of the media stage.

In the eyes of journalists, the media are especially short-time producers. They characterize the information marked by a temporality they call a "crusher" (14) that can be obtained "through information leaks" (I11) and that can also be speculative. Therefore, they often reveal that it is difficult or impossible to overcome the permanent shortage of time, the need for speeding up information, to respond to the expectation of novelty, quasi-obligation (17), that is, to first report "first" (17). That is, in circumstances that create the continuous experience of liquidity, mobility and instantaneity. The following excerpts demonstrate this idea:

media also need time to get adapted to the new realities of the world, especially as regards the working processes. The media, roughly speaking, treat subjects superficially, it is like a bubble of time, with beginning, middle and end, that is, until another controversy arises and the older one falls asleep. Mea culpa. (110)

Because of the eagerness to give things, because we have this dynamic, we take people to believe that those processes, that those times of justice should be much shorter. (I26)

In any case, the journalists interviewed do not consider that there is a homogeneous, typical and unique time that reflects the quality of the times that are produced and reproduced in cases of mediation of corruption phenomena in which politicians are targeted. They identify various temporal phases in the way the media deal with news. In this understanding, the intense instantaneousness that shapes the moments of unmasking dissipates as the cases begin to be treated in court, falling into "dead time", when the information "calms", and becomes "more of the same" (115). That is, the emergency that characterizes temporality in the case disclosure phase, gives way to the silence, in subsequent phases, when the memory about certain news dissipates.

The journalists say that in the phenomenon of corruption is important to perceive the dissonance they experience between the need to respond to the short term - by putting news in the public space - and the interest in deepening the stories researching for more contextual information. Although they identify that dissonance, they argue that the cases of corruption, because they involve politicians, fuel acceleration, in detriment to the timeless time needed for research. This happens, for example, as regards the analysis of processes, as well as of implications and of possible penalties. 
To sum up, time is a category of the journalists' discourses. It links to the need they feel to respond to the socio-political rhythms with an anticipated story that lies behind the event itself (and the news). So, they consider that acceleration serves to classify the economic and organizational models of journalism today. Although some of them criticize the immediacy and the need to respond instantly, most of the interviewees consider this is inevitable, as well as normal in the present day context:

and these things are very bad because they often lead to the risk of making a judgment in the public space, as well as a premature condemnation. There is no perfect method, so many mistakes were made. But ... there it is again ... the newspapers duty is to display the information they have, trying to make it as reliable as possible. $(128, \mathrm{Q} 25)$

Overall, however, the interviews account for the dessynchrony of times between media and justice and this implies negative perceptions for citizens about the correctness of the judicial action on the politicians. In addition, journalist say it is very clear the need for anticipation, as well as the need to "predict" and "advance" parts of the known court decisions.

The problem is this: since there are different times, on the one hand, the lack of communication, on the other, causes misunderstandings in the population regarding court decisions. Of course, they need their time, and we need ours, sometimes it's not compatible, so when they're investigating, we're trying to spread it alreay ... we want to be ahead of them, right? (127, Q26)

In addition to the importance of time in the daily activity of journalists dealing with news about corruption involving politicians, the interviews account for temporal constraints arising from the relationships they establish with judicial institutions. They consider this carries out tensions between the media times and the times of the judicial processes. In the next point we will give more attention to this subject.

\section{THE WAITING AND THE TIME OF JUSTICE}

Journalists interviewed find it difficult to manage the wait for decisions and/or contingency judicial information (for example, prosecution) or structural (and procedural) decisions and/or information. In this sense, they classify the slowness of the processes a "sin" (E6). That is, in addition to negatively shaping the times of the news, it is something that augments the underestimation of justice before the society.

Several studies argue that the media and justice should be joined by the same purpose of finding the truth (Évora, 2004, Machado \& Santos, 2008, 2011; Prior, 2013, B. de S. Santos, 2005). However, the communication between the two fields is an interaction highly mediated by waiting. Although it is typical of judicial temporality, the institutionalization of the waiting and the use of time as a means of confirmation and evaluation gives to know the establishment of power relations between media and justice. 
[During the exposition of case X] The journalists were in the street, in the rain, in the wind, in the cold. In November. 48 Hours in a row. Without information except at the end, when a lady comes to read a paper. (I17).

Journalists consider the judicial system as an institution that totalizes and standardizes time by not considering the diversity of media time and by reacting in a uniform and time-consuming manner, in face of with great media interest (and value-news), as are the cases involving corruption allegations.

Because I think that if journalists had access to basic information, already predefined, about each of the processes, maybe they would not have to walk through doors and sleepers and stick to get information, because when it is like this, whether the danger of passing erroneous information, inaccurate information, or information that goes beyond what it would take $\left(\mathrm{I}_{4}, \mathrm{Q} 13\right)$

From this point of view, it is observed that the themes analyzed are interlinked.

\section{FINAL NOTE: THE RELEVANCE OF TIME IN THE MEDIA, JUSTICE AND POLITICAL INTERACTIONS}

In 2005, Joaquim Fidalgo and Madalena Oliveira argued about the need for a closer link between media, politics and justice. In 2013, Ana Paula Lourenço wrote about the need to create channels of communication between each of these systems, suggesting the inclusion of communication offices in the judicial and police institutions. In the opinion of the author, it would facilitate the relations between journalists and justice and reduce information leakage, as well as the disclosure of justice confidential documents. It adds that this process would require a great deal of justice (adapting to the temporal patterns of media), but also of the journalists, in order to be more specialized in these areas.

Nicklas Luhmann (2005) suggests that time is a central element in any system, essentially because it is trough time that the system differentiates, develops and establishes communicative relations with other systems. Interestingly, the author analyzed the media system and the legal system, having proposed that there are no specific rules regarding how chronological time intersects with the political time of the system itself. However, it is in the nature of systems that the continuous exercise of anticipation, translated by the possibility of the system exercising the presence of the future (which has not happened), in the present (which becomes the subject of the story). This self-referential perspective on time presented by Luhmann is of great interest to understand the complementarily between the two themes treated in this article. In fact, we identify the preponderance of acceleration and instantaneity as characteristics of daily time in the media. Caused by technological transformation, digitalization, globalization, and exponential expansion of the media in contemporary societies, such acceleration and speed are also reasons why media invests in anticipation and speculation.

Observing the analyzes about the phenomenon of corruption, it can be stated that in the construction of the news, journalism is challenged by different times. Namely, the 
time of the event, the time of writing, the waiting time (for information and confirmation) and the time of the case disclosure.

This text aimed to elucidate the importance of time in media coverage of corruption phenomena. It argues the need to deepen the research on how time translates the nature of the relations of power that are established between the media, judicial and political systems. In fact, we have seen that the media operate in a ubiquitous temporality, leading to a profound change in the temporality of politics itself, with impact on deliberative mechanisms and processes. Concomitantly, the time of justice is associated to waiting and regarded as being in disrepair with the urgency of the media. As a central idea, one can argue that the new temporality regimes brougth about by technologies and the new media propose actual challenges to democracy, while requesting politics and justice to adapt to emergent and instantaneous times, thought in diverse and resistant manners, are also highly dependent on the dynamics brought about by the discrepancy and conflicts between times, as these are also possible media contents.

The questions related to time and to the strategies for dealing with durations, intervals and waiting times are crucial, not only from the point of view of the theorization, but also as regards intervention. It is understood, therefore, that in affirming the need for justice to communicate with the media, in the face of high-impact phenomena, such as corruption, journalists refer to the interest in managing and organizing the time produced through the various judicial processes, as a way of improving their performance and the quality of the information that citizens access to.

Translation: Ana Moreira

\section{REFERENCES}

Albarran, A. \& Reca, A. A.(2015). Time and media markets. New York: Routledge.

Appadurai, I. (1996). Dimensões culturais da globalização. A modernidade sem peias. Lisboa: Teorema.

Araújo, B. B. de. (2013). Justiça, media e espaço público: a cobertura jornalística do julgamento do mensalão em Veja e Época. Masters dissertation, Faculdade de Letras da Universidade de Coimbra, Portugal. ARetrieved from https://estudogeral.sib.uc.pt/handle/10316/23648?mode=full

Araújo, B. (2011). A narrativa jornalística e a construção do real. Biblioteca On-Line de Ciências Da Comunicação (BOCC). Retrieved from http://bocc.unisinos.br/pag/araujo-bruno-a-narrativajornalistica-construcao-real.pdf

Barnhurst, K. G. \& Nightingale, A. W. (2017). Time, realism, news. Journalism, 19(1), 7-20.

Boda, Z. \& Szabó, G. (2011). The media and attitudes towards crime and the justice system: a qualitative approach. European Journal of Criminology, 8(4), 329-342.

Brandtzaeg, P. B. \& Lüders, M. (2018). Time collapse in social media: extending the context collapse. Social Media + Society, 4(1). https://doi.org/10.1177/2056305118763349

Burchell, K. (2014). Tasking the everyday: where mobile and online communication take time. Mobile Media Q Communication, 3(1), 36-52. 
Cardoso, G. (2014). Os media na sociedade em rede. Lisboa: Fundação Calouste Gulbenkian.

Carlson, M. \& Lewis, S. C. (2018). Temporal reflexivity in journalism studies: making sense of change in a more timely fashion. Journalism, 20(5), 642-650.

Clarke, D. (1995). Space, time, and media theory: an Illustration from the television-advertising nexus. Environment and Planning D: Society and Space, 13(5), 557-572.

Clarke, V. \& Braun, V. (2013). Teaching thematic analysis: overcoming challenges and developing strategies for effective learning. The Psychologist, 26(2), 120-123.

Coyne, S. M., Padilla-Walker, L. M., Fraser, A. M., Fellows, K. \& Day, R. D. (2014). "Media time= family time": positive media use in families with adolescents. Journal of Adolescent Research, 29(5), 663-688.

Croteau, D. \& Hoynes, W. (2001). The business of media: corporate media and the public interest. California: Pine Forge Press.

Dardenne, R. (2004). Journalism. In D. Herman, M. Jahn, \& M-L. Ryan (Eds.), Routledge encyclopedia of narrative theory (pp. 267-269). New York: Routledge.

Deuse, M. \& Witschge, T. (2016). O que o jornalismo está se tornando. Parágrafo, 4(2), 6-21. Retrieved from http://revistaseletronicas.fiamfaam.br

Dunn, A. (2005). Radio news and interviews. In H. Fulton, R. Huisman, J. Murphet \& A. Dunn (Eds.), Narrative and media (pp. 203-217). New York: Cambridge University Press.

Évora, S. L. (2004). O segredo de justiça e a investigação jornalística: A problemática dos direitos fundamentais na democracia portuguesa. Bocc - Biblioteca On-Line de Ciências Da Comunicação. Retrieved from http://www.bocc.ubi.pt/pag/evora-silvino-segredo-de-justica.pdf

Ferin, I. (2015). Da 'democratização' da Europa: democracia, media e corrupção política. Intercom: Revista Brasileira de Ciências da Comunicação, 38(1), 37-63. Retrieved from http://www.scielo.br/pdf/interc/ v38n1/1809-5844-interc-38-01-0037.pdf

Ferin, I. (2017). Democracia e corrupção política mediatizadas. In A. Moreira, E. Araújo \& H. Sousa (Eds.), Comunicação e política: tempos, contextos e desafios (pp. 65-90). Braga: Centro de Estudos de Comunicação e Sociedade, Universidade do Minho (CECS).

Fidalgo, J. \& Oliveira, M. (2005). Da justiça dos tribunais à barra da opinião pública: as relações entre a Justiça e a Comunicação Social. Braga: Universidade do Minho. Retrieved from http://hdl.handle. net $/ 1822 / 7438$

Figueiras, R. (2015). Anatomia do comentário: corrupção, noticiários e destinatários. Media Q Jornalismo Corrupção política, media e democracia, 14(26), 111-132.

Fulton, H. (2005). Print news as narrative. In H. Fulton, R. Huisman, J. Murphet \& A. Dunn (Eds.), Narrative and media (pp. 218-244). New York: Cambridge University Press.

Fulton, H., Huisman, R., Murphet, J. \& Dunn, A. (Eds.) (2005). Narrative and media. New York: Cambridge University Press.

Genette, G. (1976). Fronteiras da narrativa. In R. Barthes, A. J. Greimas,C. Bremond, U. Eco, J. Gritti, V. Morin, C. Metz, G. Genette, Análise estrutural da narrativa (pp. 255-274). Petrópolis: Vozes.

Genette, G. (1979/1996). Discursos da narrativa. Lisboa: Veja Universidade. 
Giglioli, P. P. (1996). Political corruption and the media: the tangentopoli affair. International Social Science Journal, 48, 381-394.

Greer, C. (2009). Crime and media: a reader. London: Routledge.

Guibentif, P., Vanda, G. \& Cheta, R. (2002). Comunicação social e representações do crime. Cadernos do CEJ. Lisboa: Cadernos do CEJ.

Gurevitch, M., Coleman, S. \& Blumler, J. G. (2009). Political communication - old and new media relationships. The ANNALS of the American Academy of Political and Social Science, 625, 164-181

Herman, D. (2004). Toward a transmedia narrative. In M. L. Ryan (Ed.), Narrative across media: the languages of storytelling (pp. 47-75). London: University of Nebraska Press.

Jewkes, Y. (2004). The construction of crime news. Media and Crime (pp. 35-62). Retrieved from https://www. corwin.com/sites/default/files/upm-binaries/9600_019968cho2.pdf

Lourenço, A. P. (2013). Justiça e Comunicação Social: entre a tensão e a tentação recíprocas. Jurismat, 2, $217-254$

Jones, M. \& Ormrod, J. (Eds.) (2015). Time travel in popular media: essays on film, television, literature and video games. Jefferson: McFarland \& Company.

Jowett, L., Simmons, D. \& Robinson, K. L., (Eds.) (2016). Time on television: narrative time, time travel and time travellers in popular television culture. London: I.B.Tauris \& Co Ltd.

Karstedt, S. (2002). Emotions and criminal justice. Theoretical Criminology, 6. Retrieved from http://tcr. sagepub.com/content/6/3/299.short

Kaun, A. (2014). Facebook time: technological and institutional affordances for media memories. New Media Q. Society, 16, 1154-1168.

Kaun, A. (2015). Regimes of time: media practices of the dispossessed. Time Q S Society, 24, 221-243

Keightley, E. (Ed.) (2012). Time, media and modernity. United Kingdom: Palgrave Macmillan.

Keightley, E. \& Downey, J. (2017). The intermediate time of news consumption. Journalism, 19, 93-110.

Leandro, L. F. (2012). Crime, disse ela!: contributos para o estudo da noticiabilidade do crime ...ou como nasce uma jornalista de justiça. Masters dissertation, Universidade Fernando Pessoa, Brasil. Retrieved from https://bdigital.ufp.pt/bitstream/10284/2923/1/DM_10179.pdf

Lourenço, A. P. (2013). Justiça e comunicação social: Entre a tensão e a tentação recíprocas. Jurismat, 2, 217-254

Luengo, Ó. G. (2006). E-activism: new media and political participation in europe. CONfines, 59-71. Retrieved from http://www.scielo.org.mx/pdf/confines/v2n4/v2n4a4.pdf

Luhmann, N. (1990). Sociedad y sistema. La ambición de la teoria. Universidade Autonoma de Marbelona: Paidós.

Luhmann, N. (2005). A realidade dos meios de comunicação. Paulus: S. Paulo.

Machado, H. \& Santos, F. (2008). Crime, drama e entretenimento. O caso Maddie e a meta-justiça popular na imprensa portuguesa. Coimbra. Retrieved from http://www.ces.uc.pt/publicacoes/oficina/ficheiros/310. pdf 
Machado, H. \& Santos, F. (2009). A moral da justiça e a moral dos media: julgamentos mediáticos e dramas públicos. Oficina Do CES, 333. Retrieved from http://scholar.google.com/scholar?hl=en\&btnG=Search \&q=intitle:A+moral+da+justiça+e+a+moral+dos+media:+julgamentos+mediáticos+e+dramas+públic os\#०

Machado, H. \& Santos, F. (2010). Justiça, ambientes mediáticos e ordem social. Famalicão: Húmus.

Machado, H. \& Santos, F. (2011a). Justiça, média e cidadania. In H. Machado \& F. Santos, Direito, justiça e média. Tópicos de sociologia (pp. 133-166). Porto: Afrontamento.

Machado, H. \& Santos, F. (2011b). Direito, justiça e média. tópicos de sociologia. Porto: Edições Afrontamento.

Maia, A. J. \& Borges, H. (2014). Prevenir e reprimir a corrupção em Portugal - evolução do quadro legal. In I. Ferin \& E. Serrano (Eds.), Cobertura jornalística da corrupção política: sistemas políticos, sistemas mediáticos e enquadramentos legais (pp. 109-180). Lisboa: Aletheia Editores

Miguel, L. F. (2002). Os meios de comunicação e a prática política. Lua Nova. Retrieved from http://www. scielo.br/pdf/ln/n55-56/ao7n5556.pdf

Moreira, A. (2015). "Dou uma entrevista em legítima defesa": da prisão para os ecrãs. Comunicação, Cultura e Mídia Sociais. XIV Congresso Internacional de Comunicação Ibercom. Universidade de São Paulo: Escola de Comunicações e Artes (ECA).

Moshe, M. (2011). Media time squeezing: the privatization of the media time sphere. Television New Media, $13,68-88$.

Paixão, B. (2014). A objetividade na cobertura do escândalo político e os novos propósitos de uma subjetividade objetivante. In I. Ferin \& E. Serrano (Eds.), Cobertura jornalística da corrupção política: sistemas políticos, sistemas mediáticos e enquadramentos legais (pp. 459-492). Lisboa: Aletheia Editores.

Paixão, B. (2017). O que nos dizem os média sobre os escândalos políticos - notas sobre a duração e o tempo. In A. Moreira, E. Araújo, \& H. Sousa (Eds.), Comunicação e política: tempos, contextos e desafios (pp. 45-64). Braga: Centro de Estudos de Comunicação e Sociedade (CECS), Universidade do Minho

Pina, S. (2009). Media e leis penais. Lisboa: Almedina.

Pereira, F. H. \& Adghirni, Z. L. (2011).O jornalismo em tempo de mudanças estruturais. Intexto, 1(24), 38-57.

Prior, H. (2013). A comunicação social e o discurso judiciário. Derecom, 14, 118-130.

Prior, H., Guazina, L. \& Araújo, B. (2015). Corrupção e escândalo político: o enquadramento dos escândalos Face Oculta e Mensalão na imprensa portuguesa e brasileira. Media QJ Jornalismo, 14(26), 167-185. http://dx.doi.org/10.14195/2183-5462_26_10

Reisinger, D. S. (2007). Crime and media in contemporary France. USA: Purdue University Press.

Rieffel, R. (2003). Sociologia dos media. Porto: Porto Editora.

Robinson, J. P., Barth, K. \& Kohut, A. (1997). Social impact research: personal computers, mass media, and use of time. Social Science Computer Review, 15, 65-82.

Rosenberg, H. \& Feldman, C. (2008). No time to think: the menace of media speed and the 24-hour news cycle. Continuum.

Santos, B. de S. (2005). Os tribunais e as novas tecnologias de comunicação e de informação. Sociologias, 7 , 82-109. Retrieved from http://www.boaventuradesousasantos.pt/media/Tribunais\%20e\%2onovas\%2O tecnologias_Sociologias_2005(1).pdf 
Santos, F. (2009). Jornalistas e magistrados: perspectivas cruzadas nas relações entre media e justiça. Tese de Mestrado, Instituto de Ciências Sociais e Humanidade, Universidade de Coimbra, Coimbra, Portugal.

Sennet, R. (2006). A cultura do novo capitalismo. Rio de Janeiro: Record.

Serrano, E. (2014). A corrupção política vista através das redes sociais: metodologias para o estudo de conteúdos web. In I. Ferin \& E. Serrano (Eds.), Cobertura jornalística da corrupção política: sistemas políticos, sistemas mediáticos e enquadramentos legais (pp. 493-522). Lisboa: Aletheia Editores.

Simões, M., Barriga, A. \& Jerónimo, N. (2011). Brave new world? Political participation and new media. SOTICS 2011: The First International Conference on Social Eco-Informatics (pp. 55-60). Retirado de: http:// repositorium.sdum.uminho.pt/handle/1822/21154

Sousa, L. de. (2011). Corrupção. Lisboa: Fundação Francisco Manuel dos Santos.

Sousa, L. \& Triães, J. (2007). Corrupção e ética em democracia: o caso de Portugal. OberCom - Investigação E Saber Em Comunicação. Retrieved from http://scholar.google.com/scholar?hl=en\&btnG=Search\&q=intit le:Corrupção+e+Ética+em+Democracia+:+O+Caso+de+Portugal\#o

Todorov, T. (1976). As categorias da narrativa literária. In R. Barthes, A. J. Greimas, C. Bremond, U. Eco, J. Gritti, V. Morin, C. Metz, G. Genette, Análise estrutural da narrativa (pp. 209-254). Petrópolis: Vozes.

Yang, G. \& Clark, R. (2015). Social media and time. Social Media + Society, 1(1), 1-2.

Young, K. (2004). Frame and boundary in the phenomenology of narrative. In M. L. Ryan (Ed.), Narrative across media: the languages of storytelling (pp. 77-107). London: University of Nebraska Press.

Zhang, X. \& Ha, L. (2015). Time budget, news search time cost, and news media choice. Time \& Society, 24, 201-220.

\section{BIOGRAPHICAL NOTES}

Ana Beatriz Moreira holds a master degree in Sociology and is PhD student in Communication Sciences from the University of Minho, Portugal. The thesis discusses the media narratives on political corruption in Portugal and is funded by the Foundation for Science and Technology (FCT). Her research interests have been focused on the media, politics, justice, power and political corruption. She was at the University of Santiago de Compostela (Spain) and at the University of São Paulo (Brazil), as a visiting researcher.

ORCID: http://orcid.org/o0oo-0002-2125-8022

Email: abgmoreira@gmail.com

Address: Universidade do Minho, Instituo de Ciências sociais, Departamento de Sociologia, 4710-057 Gualtar - Braga, Portugal

Emilia Rodrigues Araújo is an Auxiliary Professor at the Institute of Social Sciences, Department of sociology and researcher at the Center for Communication and Society studies. He has participated in several research projects in the themes of time, culture and mobilities in science and research. He participates in several scientific associations, having several national and international publications on the topics mentioned.

ORCID: http://orcid.org/oooo-0003-3600-3310 
Email: emiliararaujo@gmaill.com

Address: Universidade do Minho, Instituto de Ciências Sociais, Departamento de Sociologia, 4710-057 Gualtar - Braga, Portugal

Helena Sousa is full professor of Communication Sciences. She was former Chair and Vice-Chair (2004-2014) of the Political Economy Section of the IAMCR and VicePresident of the National Science Foundation (FCT) Scientific Council for Social Sciences and Humanities, she is presently Editor of the European Journal of Communication, Member of the International Council of the IAMCR and Member of the EuroMedia Research Group. She has managed national and international research projects and has a vast experience supervising doctoral (15 completed $\mathrm{PhD}$ ) and post-doctoral students (six completed). Professor Sousa is a board member of the Communication and Society Research Centre and an independent media expert for the Council of Europe.

ORCID: http://orcid.org/0000-0002-8101-0010

Email: helena@ics.uminho.pt

Address: Universidade do Minho, Instituto de Ciências Sociais, 4710-057 Gualtar Braga, Portugal

* Submitted: $10 / 9 / 2018$

* Accepted: 25/05/2019 